\title{
PEER ASSESSMENT UNTUK MENILAI KEMAMPUAN KOMUNIKASI INTERPERSONAL MAHASISWA MELALUI OPTIMALISASI KELOMPOK PRESENTASI MIKROBIOLOGI
}

\author{
Anilia Ratnasari \\ Prodi Pendidikan Biologi Universitas Wiralodra \\ anelidae9@gmail.com
}

Citasi: Ratnasari, A. 2018. Peer Assessment untuk Menilai Kemampuan Komunikasi Interpersonal Mahasiswa melalui Optimalisasi Kelompok Presentasi Mikrobiologi. Mangifera Edu Vol 2 Nomor 2. Hal 78-88

\begin{abstract}
ABSTRAK
Penelitian deskriptif ini bertujuan untuk memperoleh keterampilan komunikasi interpersonal mahasiswa calon guru biologi menggunakan lembar peer assessment melalui optimalisasi kelompok presentasi mikrobiologi. Subjek penelitian adalah 24 orang mahasiswa program studi pendidikan biologi semester 3 tahun akademik 2017/2018 yang mengontrak mata kuliah mikrobiologi. Instrumen yang digunakan adalah lembar penilaian peer asesmen. Hasil penelitian menunjukkan bahwa persentase kelompok presentasi 3 (85\%), 7 (88,3\%), dan 8 (90\%) dengan kategori sangat baik. Rerata persentase peer assessment untuk ciri atau indikator kemampuan komunikasi interpersonal yang meliputi: (1) Keterbukaan aspek yang dinilainya kemampuan menyajikan materi presentasi dengan lengkap, jelas, dan kreatif menggunakan media power point sebesar 91,7\% (sangat baik);

(2) Empati aspek yang dinilainya kemampuan menggunakan gaya bahasa tubuh pada saat presentasi sehingga terjadi interaksi antara penyaji dan audience sebesar 91,7\% (sangat baik); (3) Dukungan aspek yang dinilainya kemampuan berkolaboratif dengan kelompok presentasi dalam menjawab pertanyaan dari audience sebesar 91,7\% (Sangat baik); (4) Kepositifan aspek yang dinilainya Kemampuan menyampaikan materi presentasi dengan intonansi dan dimensi yang baik sehingga menarik perhatian audience sebesar 91,7\% (Sangat baik); (5) Kesamaan aspek yang dinilainya Kemampuan sebagai tutor sebaya memberikan penjelasan materi presentasi sehingga menjadi mudah diterima dan dipahami audience (teman sejawat) sebesar 83,3\% (baik). Jadi kemampuan komunikasi interpersonal mahasiswa calon guru biologi melalui optimalisasi kelompok presentasi mikrobiologi dapat menilai secara baik menggunakan lembar peer assessment.
\end{abstract}

Kata kunci: Peer Assessment, Kelompok presentasi, Komunikasi Interpersonal

\section{PENDAHULUAN}

Hasil belajar yang komprehensip dan bermakna menjadi fokus outcome learning dari sebuah pembelajaran, baik jenjang sekolah menengah maupun perguruan tinggi. Mendesain sebuah pengalaman belajar yang optimal untuk mahasiswa calon guru biologi memberikan ruang bagi mahasiswa untuk meningkatkan aktivitas belajar, mencari informasi terkait dengan materi, menuangkan gagasan materi yang disajikan menggunakan media, dan materi 
disampaikan kembali kepada audience. Hal tersebut dapat menggali kemampuan komunikasi interpesonal berkaitan dengan interaksi dengan dosen, dan antar mahasiswa lainnya. Komunikasi interpersonal menuntut adanya tindakan saling memberi dan menerima di antara pelaku yang terlibat dalam komunikasi. Para pelaku komunikasi saling bertukar informasi, pikiran, gagasan, dan sebagainya (Rakhmat, 2001 dalam Ahmad saudia). Sesuai dengan tujuan komunikasi interpersonal yang disebutkan Suranto, 2011 dalam Martha Ratih, 2013 mengemukakan sebagai berikut; 1) Mengungkapkan perhatian pada orang lain; 2) Menemukan diri sendiri; 3) Menemukan dunia luar; 4) Membangun dan memelihara hubungan sosial; 5) Mempengaruhi sikap dan tingkah laku; dan 6) Mencari kesenangan atau sekedar menghabiskan waktu.

Kemampuan berkomunikasi setiap mahasiswa berbeda-beda terbukti pada kegiatan kelompok presentasi biasanya penyaji oleh satu orang mahasiswa saja, Ada pula audience yang tidak menyimak materi ketika penyaji menyampaikan materi karena mengalami kesulitan dalam berkomunikasi. Kesulitan yang dialami oleh mahasiswa sebagai penyaji pada umumnya disebabkan masih kurang memiliki kemampuan komunikasi yang baik. Optimalisasi kelompok presentasi sebagai sarana menggali kemampuan komunikasi untuk menyampaikan pesan dengan cara menjelaskan atau menguraikan suatu materi secara lisan, sistematis dan efektif baik untuk pembawa presentasi maupun penerima. Tujuan presentasi dilihat dari tipe presentasinya dapat dinyatakan sebagai berikut; menyampaikan informasi, hasil-hasil temuan, dan analisis untuk menarik audience agar menerima sesuatu yang sedang ditawarkan menjadi sesuatu yang dibutuhkan audience. Syarat presentasi meliputi: 1). Menguasai bahasa dengan baik, 2). Mempunyai keberanian, 3). Adanya ketenangan sikap, 4). Sanggup mengadakan reaksi yang cepat dan tepat, 5). Sanggup menampilkan gagasan secara lancar dan teratur, 6). Memperlihatkan sikap yang tidak kaku dan tidak canggung (http://mcd.bis.telkomuniversity.ac.id).

Presentasi merupakan bagian dari aktifitas performance mahasiswa dalam proses pengalaman belajar. Penilaian yang sesuai dengan presentasi adalah penilaian otentik dengan penggunaan asesmen alternatif. Gabel, 1993 mengkategorikan peer asesment merupakan bagian dari asesmen alternatif yang memiliki ciri sebagai berikut: 1). Menuntut siswa untuk merancang, membuat, menghasilkan, mengunjukkan atau melakukan sesuatu; 2). Memberi peluang untuk terjadinya berpikir kompleks dan/atau memecahkan masalah; 3). menggunakan kegiatan-kegiatan yang bermakna secara instruksional; 4). Menuntut penerapan yang autentik pada dunia nyata; 5). Pensekoran lebih didasarkan pada 
pertimbangan manusia yang terlatih dari pada mengandalkan mesin (Popham (1995:4-13 dalam Anna Ratnawulan).

Keaten, Richardson, \& Elizabeth (1993) mendefinisikan asesmen teman sejawat sebagai proses dimana para mahasiswa menilai mahasiswa yang lainnya; menilai atau mengomentari perkerjaan mahasiswa yang lainnya; menilai seberapa besar mereka memberi kontribusi terhadap kelompoknya, dan dapat merefleksikan kekuatan dan kelemahan kelompoknya. Johnson \& Johnson (2002) menyatakan bahwa alasan-alasan melibatkan mahasiswa dalam kegiatan asesmen, antara lain: (1) dapat meningkatkan kualitas keputusan yang diambil tentang asesmen akibat memanfaatkan sumberdaya mahasiswa, (2) dapat meningkatkan komitmen mahasiswa untuk menerapkan cara asesmen yang terbaik, (3) dapat mengurangi sikap resisten mahasiswa terhadap umpan balik dan perlunya perubahan, (4) dapat meningkatkan prestasi siswa, (5) dapat mendorong motivasi yang besar untuk belajar dan membangun sikap belajar yang positif dan asesmen, dan (6) dapat meningkatkan asesmen diri (self assessment).

Peer assessment berpedoman pada lembar observasi presentasi kelompok, dan oral feedback. Peer assessment dapat diterapkan dalam menilai kemampuan non kognitif mahasiswa yaitu menilai kemampuan komunikasi interpersonal mahasiswa melalui optimalisasi kelompok presentasi mikrobiologi. Berdasarkan kondisi tersebut penelitian ini bertujuan mengetahui peer asessment untuk menilai kemampuan komunikasi interpersonal mahasiswa melalui optimalisasi kelompok presentasi mikrobiologi.

\section{METODE PENELITIAN}

Metode yang digunakan pada penelitian ini adalah deskriptif. Penelitian ini dilakukan Fakultas Keguruan dan Ilmu Pendidikan Program Studi pendidikan Biologi Universitas Wiralodra Indramayu, subjek yang digunakan dalam penelitian ini adalah mahasiswa Pendidikan Biologi semester 3 tahun ajaran 2017/2018 sebanyak 24 orang yang mengontrak mata kuliah Mikrobiologi. Pemilihan subjek dilakukan dengan menggunakan teknik purposive sampling. Penelitian ini dilakukan selama 2 bulan terhitung mulai dari bulan Nopember sampai Desember 2017.

Instrumen yang digunakan pada penelitian ini adalah lembar peer asesmen sebagai lembar penilaian kemampuan komunikasi interpersonal mahasiswa melalui optimalisasi kelompok presentasi dalam penyampaian materi mikrobiologi yang dibagikan pada masaing-masing kelompok. 
Pengambilan data dilakukan setiap kelompok presentasi bergantian saling menilai; kelompok 1 dinilai kelompok 2, kelompok 2 dinilai kelompok 3, kelompok 3 dinilai kelompok 4, kelompok 4 dinilai kelompok 5, kelompok lima dinilai kelompok 6, kelompok 6 dinilai kelompok 7, kelompok 7 dinilai kelompok 8, dan kelompok 8 dinilai kelompok 1. Adapun pengolahan data lembar peer dan assessment dengan menggunakan rumus Purwanto (2009 dalam Aa Juhanda, 2017).

Keterangan :

$$
\mathrm{NP}=\mathrm{R} / \mathrm{SM} \times 100 \%
$$

$\mathrm{Np} \quad$ : Nilai persen yang dicari atau diharapkan

$\mathrm{R} \quad$ : Skor mentah yang diperoleh siswa

$\mathrm{Sm} \quad$ : Skor maximum ideal dari tes yang bersangkutan

$100 \%$ : Bilangan tetap berkut:

Kategorisasi berdasarkan Arikunto (2010) seperti ditujukkan pada tabel 2 sebagai

Tabel. 2. Kategori peer asessment

\begin{tabular}{|c|c|}
\hline Presentase & Predikat \\
\hline $81-100 \%$ & Baik Sekali \\
\hline $61-80 \%$ & Baik \\
\hline $41-60 \%$ & Cukup \\
\hline $21-40 \%$ & Kurang \\
\hline$<21 \%$ & Kurang Sekali \\
\hline
\end{tabular}

Sumber:: (Suharsimi, 2010)

\section{HASIL DAN PEMBAHASAN}

Pada penelitian ini menilai kemampuan komunikasi interpersonal mahasiswa pendidikan biologi melalui optimalisasi presentasi pada mata kuliah mikrobiologi yaitu dengan menggunakan lembar peer asesement sebagai alat ukur yang digunakan mahasiswa saling menilai antar kelompok presentasi mahasiswa. Adapun data yang diperoleh berupa hasil peer asesement kelompok presentasi mahasiswa dari kelompok 1 dinilai kelompok 2 , kelompok 2 dinilai kelompok 3, kelompok 3 dinilai kelompok 4, kelompok 4 dinilai kelompok 5, kelompok 5 dinilai kelompok 6, kelompok 6 dnilai elompok 7, kelompok 7 dinilai kelompok 8, dan kelompok 8 dinilai kelompok 1 . Hasil presentase data disajikan pada tabel 3 sebagai berikut: 
Tabel. 3. Hasil Peer Asessment kemampuan komunikasi Interpersonal Mahasiswa melalui optimalisasi kelompok presentasi mikrobiologi

\begin{tabular}{|c|c|c|c|}
\hline $\begin{array}{c}\text { Kelompok } \\
\text { presentasi } \\
\text { Mahasiswa }\end{array}$ & $\begin{array}{l}\text { Materi Presentasi } \\
\text { Mikrobiologi }\end{array}$ & Presentase & Kategori \\
\hline Kelompok 1 & Bakteri & $66,7 \%$ & Baik \\
\hline Kelompok 2 & Virus & $53,3 \%$ & Cukup \\
\hline Kelompok 3 & Mikro Fungi & $85 \%$ & Sangat Baik \\
\hline Kelompok 4 & Alga & $68,3 \%$ & Baik \\
\hline Kelompok 5 & Protooa & $46,7 \%$ & Cukup \\
\hline Kelompok 6 & $\begin{array}{l}\text { Peranan } \\
\text { mikrobiologi dalam } \\
\text { bidang pertanian }\end{array}$ & $36,7 \%$ & Kurang \\
\hline Kelompok 7 & $\begin{array}{l}\text { Peranan } \\
\text { mikrobiologi dalam } \\
\text { bidang industri dan } \\
\text { farmasi }\end{array}$ & $88,3 \%$ & Sangat Baik \\
\hline Kelompok 8 & $\begin{array}{l}\text { Peranan } \\
\text { mikrobiologi dalam } \\
\text { bidang makanan } \\
\text { dan minuman }\end{array}$ & $90 \%$ & Sangat Baik \\
\hline \multicolumn{2}{|c|}{ Rerata } & $67 \%$ & Baik \\
\hline
\end{tabular}

Temuan pada tabel 3 bahwa hasil peer asessment untuk menilai kemampuan komunikasi interpersonal mahasiswa melalui optimalisasi kelompok presentasi mikrobologi, menunjukkan hasil presentasi peer asessment yang berbeda-beda antar masing-masing kelompok presentasi. Pada kategori baik kemampuan komunikasi interpersonal sebanyak 6 orang mahasiswa terdiri dari kelompok presentasi 1 dan 4 dengan persentase 66,7\% dan 68,3 \%. Kemudian 6 orang mahasiswa dengan kategori cukup kemampuan komunikasi interpersonal pada kelompok presentasi 2 dan 5 dengan presentase 53,3\% dan 46,7\%. Kategori kurang hanya 3 orang mahasiswa yaitu kelompok presentasi 6 dengan persentase kemampuan komunikasi interpersonal sebesar 36,7\%. Sedangkan paling banyak 9 orang mahasiswa memiliki kemampuan komunikasi interpersonal dengan kategori sangat baik yaitu; kelompok presentasi 3 dengan materi presentasi mikro fungi mendapatkan presentasi peer asesmen kemampuan komunikasi interpersonal sebesar 85\% kategori sangat baik dengan kategori sangat baik, kelompok presentasi 7 dengan materi presentasi peranan mikrobiologi mendapatkan presentasi peer asesmen kemampuan interpersonal sebesar $88 \%$ 
kategori sangat baik, dan kelompok presentasi 8 dengan materi presentasi peer asesmen kemampuan interpersonal sebesar 90\% kategori sangat baik. Hal tersebut menunjukkan bahwa pembelajaran dengan optimalisasi kelompok presentasi dapat menggali kemampuan komunikasi interpersonal mahasiswa sejalan dengan Mulyana, 2007 dalam, komunikasi interpersonal adalah komunikasi antara orang-orang secara tatap muka, yang memungkinkan setiap pesertanya menangkap reaksi orang lain secara langsung, baik secara verbal maupun non-verbal. Merujuk De Vito dalam Sendjaja, 2004 dikutip ahmad saudia manajemen interaksi seseorang yang menginginkan komunikasi yang efektif akan mengontrol dan menjaga interaksi agar dapat memuaskan kedua belah pihak, sehingga tidak seorang pun merasa diabaikan. Komunkasi interpersonal merupakan suatu proses pengiriman pesan dari seseorang kepada orang lain atau beberapa orang baik verbal maupun non verbal yang ditanggap oleh orang lain, maka ini sesuai dengan yang terjadi dalam kegiatan optimalisasi kelompok presentasi.

Komunikasi interpersonal membutuhkan orientasi pada orang lain untuk mencapai efektivitas komunikasi, seseorang harus memiliki sifat yang berorientasi pada orang lain, artinya adalah kemampuan seseorang untuk beradaptasi dengan orang lain selama berkomunikasi interpersonal. seseorang harus mampu melihat perhatian dan kepentingan orang lain. selain itu, orang yang memiliki sifat ini harus mampu merasakan situasi dan interaksi dari sudut pandang orang lain serta menghargai perbedaan orang lain dalam menjelaskan suatu hal, dan sejalan dengan tujuan komunikasi interpersonal yaitu agar dapat bersosialisasi dengan orang lain dan membantu orang lain melalui komunikasi antar pribadi kita dapat menjadikan diri sebagai suatu sumber yang dapat mengubah diri dan lingkungan sesuai dengan yang kita hendaki (Djoni Aminudin, 2012).

Mahasiswa akan memiliki komunikasi interpersonal yang baik jika memiliki tujuan 1).Beajar dengan melakukan komunikasi antar pribadi akan dapat memperluas wawasan tentang objek kejadian maupun dunia luar, 2). Berhubungan yaitu menjaga relasi atau interaksi dengan orang lain serta mengoptimalkan kemampuan senantiasa menilai diri dan orang lain secara positif, 3). Mempengaruhi antar pribadi bertujuan untuk mempengaruhi orang lain agar dapat mengikuti apa yang dikemukakan oleh komunikator sehingga dapat berpartisipasi dalam kegiatan bersama yaitu dalam kegiatan optimalisasi kelompok pesentasi mikrobiologi mahasiswa 


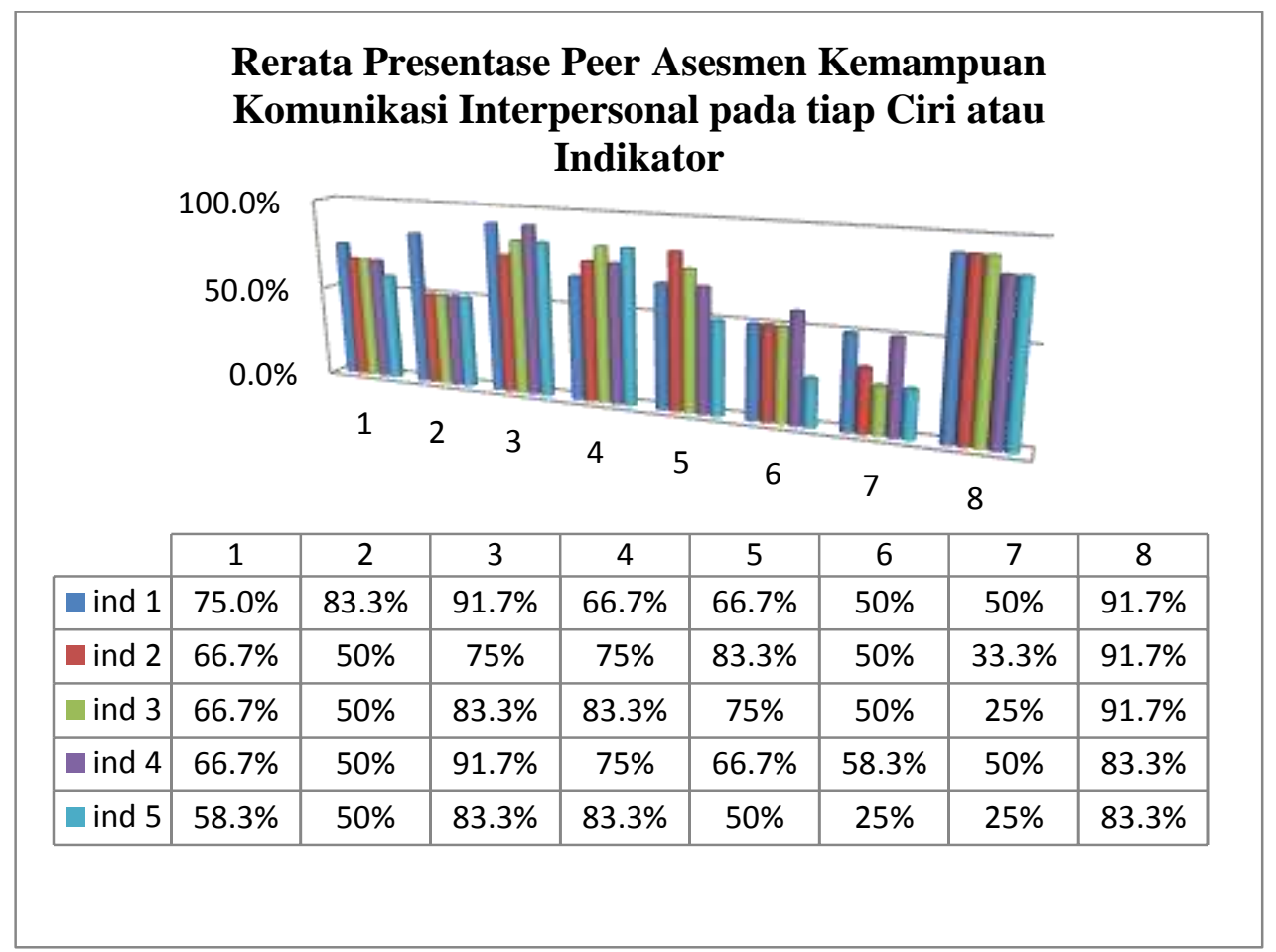

Gambar 2. Grafik rerata presentasi

Dari temuan gambar 2 grafik rerata persentase peer asesmen pada tiap indikator komunikasi interpersonal dari hasil optimalisasi kelompok presentasi mikrobiologi yaitu pada ciri atau indikator 1 yaitu keterbukaan dan aspek yang dinilainya dalam kemampuan menyajikan materi presentasi dengan lengkap, jelas, dan kreatif menggunakan media power point memiliki rerata presentasi tertinggi sebesar $91,7 \%$ pada kelompok presentasi 3 dan 8 serta presentasi terendah sebesar 50\% pada kelompok presentasi 6 dan 7. Hal tersebut menunjukan tidak semua kelompok presentasi dapat memiliki keterbukaan pada kemampuan komunikasi interpersonal. Sesuai dengan karakteristik dari komunikasi interpersonal perspektif humanistik yang meliputi sifat keterbukaan tentang komunikasi interpersonal yaitu terbuka pada orang- orang yang berinteraksi sehingga orang lain akan mengetahui pendapat, pikiran dan gagasan kita, sehingga komunikasi akan mudah dilakukan. Keterbukaan menunjukkan pada kemauan diri untuk memberikan tanggapan 
terhadap orang lain dengan jujur dan terus terang tentang segala sesuatu yang dikatakannya. Keterbukaan diperlukan dengan cara memberi tanggapan secara spontan dan tanpa dalih terhadap komunikasi dan umpan balik orang lain (De Vito dalam Sendjaja, 2004 dikutip oleh Achmad Saudia). Ciri seorang atau mahasiswa yang memilki keterukaan dalam kemamuan komunikasi interpersonal yaitu a). Menilai pesan secara objektif dengan menggnaka data dan logika, b). Mudah membedakan suasana dan sebagainya, c).Berorietasi pada isi, d). Mencari informasi dari berbagai sumber, e). Mencari pengertian pesan yang tidak sesuai dengan yang dipercayainya (Brooks dan Emmert dalam Rahmat, 2007:136, dikutip Djoni Aminudin, 2012).

Ciri atau indikator 2 kemampuan komunikasi interpersonal yaitu empati dan aspek yang dinilainya kemampuan menggunakan gaya bahasa tubuh pada saat presentasi sehingga terjadi interaksi antara penyaji dan audience, memiliki rerata presentasi tertinggi sebesar 91,7\% hanya pada kelompok presentasi 8 dan presentasi terendah 33,3\% pada kelompok presentasi 7 saja. Karakteristik Empati adalah kemampuan seseorang untuk menempatkan dirinya pada peranan atau posisi orang lain dalam arti seseorang secara emosional maupun intelektual mampu memahami apa yang dirasakan dan dialami orang lain. Empati adalah aspek dari komunikasi interpersonal yang berkaitan dengan merasakan sebagaimana yang dirasakan oleh orang lain yakni mencoba merasakan dalam cara yang sama dengan orang lain. Kita dapat mengkomunikasikan empati secara verbal dan non-verbal. Sikap empati bersesuain dengan perilaku ekspresif yaitu memperlihatkan keterlibatan seseorang secara sungguh-sungguh dalam berinteraksi dengan orang lain. Kemampan komunikasi interpersonal empati tidak hanya berkaitan dengan aspek kognitif, tetapi juga mengandung aspek afektif dan ditujukan dalam gerakan cara berkomunikasi (mengandung dimensi kognitif, afektif, perseptual, somatic/kinesthetic, apperceptual, dan communicative) (Jumarin, 2002:97 dalam Djoni Aminudin, 2012). Perilaku ekspresif ini hampir sama dengan keterbukaan, mengekspresikan tanggung jawab terhadap perasaan dan pikiran seseorang, terbuka pada orang lain dan memberikan umpan balik yang relevan. Orang yang berperilaku ekspresif akan menggunakan berbagai variasi pesan baik secara verbal maupun non verbal, untuk menyampaikan keterlibatan dan perhatiannya pada apa yang sedang dibicarakan (De Vito dalam Sendjaja, 2004 dikutip oleh Achmad Saudia).

Ciri atau indikator 3 kemampuan interpersonal yaitu dukungan dan aspek yang dinilainya kemampuan berkolaboratif dengan kelompok presentasi dalam menjawab pertanyaan dari audience, memiliki rerata presentasi tertinggi sebesar 91,7\% dan pada kelompok presentasi 8 juga, sehingga mendapat kategori kelompok presentasi sangat baik, 
dan presentasi terendah 25\% pada kelompok presentasi kelompok 7. Ciri dukungan adalah aspek dari komunikasi interpersonal yang berkaitan dengan pemberian dukungan yang berbentuk ucapan maupun gerakan (Devito dalam Thoha, 2003 dikutip oleh Dewi Aswida Br Sagala dan Hasan Saragih). Dukungan merupakan pemberian dorongan semangat kepada orang lain dalam suasana hubungan komunikasi, sehingga dengan adanya dukungan dalam situasi tersebut, komunikasi interpersonal akan bertahan lama karena tercipta suasana yang mendukung (Djoni Aminudin, 2012).

Ciri atau indikator 4 kemampuan komunikasi interpersonal yaitu kepositifan dan aspek yang dinilainya kemampuan menyampaikan materi presentasi dengan intonansi dan dimensi yang baik sehingga menarik perhatian audience memiliki rerata presentasi tertinggi sebesar $91,7 \%$ hanya pada kelompok presentasi 3, dan presentase terendah sebesar 50\% pada kelompok presentasi 2 dan 7, oleh karena selaras dengan teori perilaku positif komunikasi interpersonal akan efektif bila memiliki perilaku positif. Sikap positif dalam komunikasi interpersonal menunjuk paling tidak pada dua aspek, yaitu: 1) Komunikasi interpersonal akan berkembang bila ada pandangan positif terhadap diri sendiri. 2) mempunyai perasaan positif terhadap orang lain dan berbagai situasi komunikasi. Dan juga bersikap yakin komunikasi interpersonal akan lebih efektif bila seseorang mempunyai keyakinan diri bahwa seorang tidak merasa malu, gugup atau gelisah menghadapi orang lain. dalam berbagai situasi komunikasi, orang yang mempunyai sifat semacam ini akan bersikap luwes dan tenang, baik secara verbal maupun non verbal (De Vito dalam Sendjaja, 2004 dikutip oleh Achmad Saudia). Kesuksesan komunikasi interpersonal banyak tergantung pada kualitas pandangan dan perasaan diri postif dan negatif. Pandangan dan perasaan tentang diri yang positif akan lahir pola perilaku komunikasi antar pribadi yang positif pula (Rahmat, 2007:105, dalam Djoni Aminudin, 2012).

Ciri atau indikator 5 kemampuan komunikasi interpersonal yaitu kesamaan dan aspek yang dinilainya kemampuan sebagai tutor sebaya memberikan penjelasan materi presentasi sehingga menjadi mudah diterima dan dipahami audience (teman sejawat), memiliki rerata presentasi tertinggi sebesar 83,3\% pada kelompok presentasi 3,4,dan 8, dan presentase terendah sebesar 25\% pada kelompok presentasi 6 dan 7, menunjukkan kemampuan ketiga kelompok presentasi tersebut mendapatkan kategori baik. Hal demikian didukung teori bahwa kebersamaan seseorang bisa meningkatkan efektivitas komunikasi interpersonal dengan orang lain bila ia bisa membawa rasa kebersamaan. Orang yang memiliki sifat ini, bila berkomunikasi dengan orang lain akan memperhatikannya dan merasakan kepentingan orang lain (De Vito dalam Sendjaja, 2004 dikutip oleh Achmad 
Saudia). Kemampuan komunikasi antar pribadi dalam kesetaraan atau kesamaan merupakan sikap memperlakukan orang lain secara horiontal dan demokratis, tidak menunjukkan diri sendiri lebih tinggi atau lebih dari orang lain karena status kekuasaan, kemampuan intelektual dalam persamaan tidak menggurui, tetapi berbincang pada tingkat yang sama melalui bimbingan teman sejawat yaitu mengkomunikasikan penghargaan dan rasa hormat pada perbedaan pendapat dan keyakinan (Rahmat, 2007:135, dalam Djoni Aminudin, 2012).

\section{KESIMPULAN}

Berdasarkan hasil pembahasan secara keseluruhan, penelitian ini dapat disimpulkan bahwa kemampuan komunikasi interpersonal baik pada kelompok presentasi maupun dari rerata presentase tiap ciri atau indikator Hasil penelitian menunjukkan bahwa persentase kelompok presentasi 3 (85\%),7 (88,3\%),dan 8 (90\%) dengan kategori sangat baik. Rerata persentase peer assessment untuk tiap ciri atau indikator kemampuan komunikasi sebesar 91,7\% (sangat sebesar da 83,3\% (baik). Jadi kemampuan komunikasi interpersonal mahasiswa calon guru biologi melalui optimalisasi kelompok presentasi mikrobiologi dapat dinilai secara baik menggunakan lembar peer assessment.

\section{DAFTAR PUSTAKA}

Aa Juhanda. (2017). Optimalisasi Diskusi Kelas Melalui Peer Assessment Dan Self Assessment Untuk Menilai Kemampuan Komunikasi Lisan Mahasiswa Calon Guru Biologi. Jurnal Pendidikan Matematika dan IPA Vol. 8 No. 2 Juli 2017: 1-9: Pendidikan Biologi Universitas Muhammadiyah Sukabumi.

Achmad Saudia. Komunikasi Interpersonal Yang Efektif Pada Kelompok Kerja X.

Anna Ratnawulan. Penggunaan Asesmen Bervariasi Pada Implementasi Model Pembelajaran Berbasis Daily Life and Hand On. FPMIPA: UPI Bandung.

Diana Tri Utami. (2013). Peranan Komunikasi Interpersonal untuk Meningkatkan Motivasi Kerja Karyawan PT. Asuransi Jiwasraya (PERSERO) Bandung. Skripsi Fakultas Bisnis dan Manajemen: Universitas Widyatama.

Dewi Aswida Br Sagala dan Hasan Saragih. Pengaruh Metode Pembelajaran Dan Komunikasi Interpersonal Terhadap Hasil Belajar Siswa Pada Mata Biologi: Universitas Negeri Medan.

Djoni Aminudin. (2012). Meningkatkan Kemampuan Komunikasi Interpersonal Siswa Melalui Bimbingan Teman Sebaya. Repository.upi.edu: Universitas Pendidikan Indonesia Bandung. 
Johnson, D., W. \& Johnson, R., T. (2002). Meaningful assessment: Amanageable and cooperative process. Boston: Allyn \& Bacon.

Keaten, J., A., Richardson, \& Elizabeth, M. (1993). A field investigation of peer assessment as part of the student group grading process.(versi electronic) EDRS ED 361753. (diambil pada tanggal 20 Pebruari 2007).

Gabel , D.L.(1993). Handbook of Research on Science Teaching and Learning. New York: Maccmillan Company.

Siti Sriyati, dkk.2010. Kontribusi Asesmen Alternatif Terhadap Habist Of Mind Mahasiswa Biologi. Jurnal Pengajaran MIPA Vol .5 No.2: SPs UPI Bandung.

http://mcd.bis.telkomuniversity.ac.id. 